human interconnectedness, as they are found in the world's diverse literatures?

Rey Chow notes that globalization for colonial peoples "hats always meant the evacuation of their native cultures and languages" (73). Said points to the persistence of "the assumption that 'we' can survey the world, redraw the boundaries, give sanction to (or withhold it from), some histories, languages, voices, experiences" (67). This issue of PMLA does little to dispel these anxieties.

Balachandra Rajan University of Western Ontario

\section{Legacies of Canaan and Etruria}

\section{TO THE EDITOR:}

After reading Carlos Alonso's description of PMLA's rigorous review process (Editor's Column, 116 [2001]: 9-15), I was dismayed to discover in the same issue Basem L. Ra'ad's regrettably misinformed "Primal Scenes of Globalization: Legacies of Canaan and Etruria" (89-110). By discussing Western culture's wholesale appropriation, distortion, and demonization of these accomplished ancient cultures, Ra'ad aims to establish common ground between the contemporary Middle East and the West. But in the name of healing and redress, $\mathrm{Ra}$ ' ad engages in the same "imperial" practices he decries, presenting a skewed treatment of the Hebrew Bible and of much contemporary biblical scholarship as well as promoting a fraudulent history.

$\mathrm{Ra}$ 'ad reads the biblical narrative both as a mere mass of "redacted derivatives," which is to say a patchwork of stolen Canaanite, Egyptian, Babylonian, and Philistine goods (99), and as a fixed national history that encourages the dispossession and maltreatment of non-"Israelites" (99, 101, 103). ( $R a$ 'ad's repeatedly enclosing this national name but no other in ironic quotation marks does little to convince me of the sincerity of his stated commitment to discovering human "commonality" [89].) However, as is demonstrated by contemporary literary scholars, the issue of redaction, like the longrecognized presence of mythic sources, while interesting, is hardly the whole story of Hebrew biblical narrative. Riddled with word play, ambiguity, and ellipsis, this narrative is not static but capable of transformation through time, a subtle and complex art form. (It is worth recalling here that rabbinic discussion of the biblical narrative is one of the matrices of Derridean deconstruction, whose besiegement by the academy, Ra'ad warns, "threaten[s] to erase all advances in critical analysis" [91].)

As Robert Alter points out in The Art of Biblical Narative, the nature of the Hebrew narrative is such that, far from dictating static truths, it involves the reader in a "process" of questioning meaning, making judgments that are always subject to revision, inquiring into the purposes of God ([New York: Basic, 1981] 12). From this perspective, it is not too much to say that the biblical narrative brings down to earth the cosmic battlegrounds of the older myths and in so doing provides a ground for humanizing growth, a place to wrestle, like JacobIsrael, with (the nature of the self "made in the image of") God. Certainly this is the self-expansive direction in which recent feminist biblical criticism tends. For example, in Counter-traditions in the Bible: A Feminist Approach, Ilana Pardes recuperates female voices millennially silenced by exclusionary male scholarship (Cambridge: Harvard UP, 1992). Likewise, in Three Steps on the Ladder of Writing and elsewhere, Hélène Cixous discovers in the book of Genesis a window to the unconscious, the realm of connection with all life through the mother ([New York: Columbia UP, 1993] 67).

Even at its most superficial level, the Hebrew biblical narrative insists on human interconnection. This narrative begins not with Hebrew history but with stories of the creation of all humanity. Focused though they are on the fortunes of Israel, the books of the Hebrew Bible are connected by a thread that attempts to balance the relation between power and subordination, self-interest and concern for the "other." Recall, for example, God's equalizing reminder to Israel in Amos 9.7, "Are you not as the children of the Ethiopians to me [. . .]?" Recall the prophet Nathan's parabolic rebuke to David when the king wantonly abuses his power over Uriah the Hittite (2 Sam. 11.2-12.7). Recall Abraham's bargaining with God on behalf of the Sodomites; Judah's contrite recognition of his greater guilt in the matter of Tamar; Joseph's storing up food to preserve the lives of people of all lands in a time of famine (Gen. 18.23-32, 38.26, 41.57). Recall the repeated Levitical injunction to "love your neighbor as yourself" (Lev. 19.18, 34). 
Ra'ad diminishes his credibility not only when he refuses to acknowledge the art and hospitality of the Hebrew Bible while stressing the artistic achievements and hospitality of earlier cultures (104) but also when he bends the truth about biblical scholarship. The authors of the essays in Alter and Frank Kermode's Literary Guide to the Bible, for example, do not, as Ra ad asserts they do, "rely on the King James translation" ( 100$)$, whose "serious philological deficiencies" and possibly "misleading" archaisms the editors freely admit ([Cambridge: Belknap-Harvard UP, 1987] 7). Rather, as is plainly stated in the general introduction, these authors use the King James version for its familiarity among readers of English. and they "revise it" when necessary, indicating their revisions with various markings (8). Ra' ad likewise tarnishes his scholarship when he omits contemporary Hebrew from his list of languages informed by Canaanite roots and connected with the ancient past through them. An Israeli woman, just like a Palestinian woman, "may refer to her husband as "my ba' al" " (Ra'ad 94) and so on. Such distortions and omissions, like Ra'ad's attempt to delegitimate the Bible of the Israelites as a source of humane relations with others, bespeak his zeal for delegitimating the contemporary nation of Israel. That as much as a desire to restore ancient cultures to deserved prominence is the agenda that surfaces with nearly every turn of Ra' ad's essay. That is the agenda of Keith Whitelam's The Invention of Ancient Israel: The Silencing of Palestinian History, which Ra'ad promotes and for whose wishful claim that the contemporary Palestinians are the direct heirs of the non-Israelites who lived in ancient Palestine there exists not one shred of evidence. (For a fuller rebuttal to Whitelam's book, see the review by Baruch A. Levine and Abraham Malamat in Israel Exploration Joumal 46 [1996]: 284-88.)

Ra'ad's "project to translate new scholarship on the eastern Mediterranean into public information" is a valuable one (89). But this essay rests on halftruths and questionable scholarship and therefore has no place in so fine and prestigious a journal as $P M L A$.

Charlotte Berkowitz University of Houston, University Park

\section{Reply:}

Even quotation marks are in the eyes of the beholder. I use this device fourteen times for "Phoeni- cian(s)" - compared with eight for "Istaclite(s)." I also employ the device for "Indians," "Arabs," and. sometimes, "Canaanites." Would pointing out Charlote Berkowitz's selective reading change her view that I enclose on/y "this national name ["Israclites"] but no other in ironic quotation marks"?

The contexts reveal that these entities are idealized. constructed, or abused, to project monolithic, stereotyped images. "Phoenicians" were coastal Canaanites whose culture and language inventories are most fully continued in present Arabic. Some Lebanese groups, however, identify with "Phoenicians" to distance themselves from the "Arab" environment. Zionism elides distinctions in terms like Jew, Israelite, and Hebrew (and distorts terms like Arab) to simplify the region's demographic complexity, confuse ethnicity with religion, and create physical and historical connections that do not exist in fact.

My essay exposes abuses of religious texts by those whose real business is not religion (as in colonial endeavors that include Israel's today). It analyzes the construct "Western civilization," using many sources and an eclectic critical approach. Berkowitz's comments skirt my essay, reduce the larger historical and cultural argument to her political misconstruction, and romanticize what many see as a regressive patriarchal model. Her citations aro inaccurate and unsupported by my text. Nowhere do I say. as she contends I do, that "Israelites" took anything from "Philistines." Only Berkowity uses terms like "mere mass" and "a patchwork of stolen [. . .] goods" about biblical narratives. I emphasize the Bible's complexity and deep origins and call for a "richer appreciation" of it (91,98-99).

Regarding Alter and Kermode on the Bible, Berkowitz chooses only half my phrase and ignores "official religious references" (100). As I show (99), official revisions still hesitate to disturb established notions and fail to reveal more accurate renderings of passages such as Exodus 6.3 and Psalm 82. The same occurs in translations of significant inscriptions (98). A more suitable guide to the Bible as literature is the one by Gabel, Wheeler, and York.

A Jewish colleague, who supports my essay. asked me to apply my ideas to present Palestine/ Israel. Berkowitz, who echoes my terms but obscures my issues, thinks that is already my "agenda." (Coy praise for PMLA that devalues work published in it is 